\title{
PHYLOGENETIC POSITION AND TAXONOMIC DISPOSITION OF TURRAEA BREVIFLORA (MELIACEAE), A HITHERTO ENIGMATIC SPECIES
}

\author{
A.N. MUELLNER ${ }^{1} \&$ D.J. MABBERLEY ${ }^{2}$
}

\begin{abstract}
SUMMARY
For decades, the rare Malesian shrublet hitherto called Turraea breviflora, was the only species of the pantropical family Meliaceae which could not confidently be placed in a genus. Previous morphological re-investigation led to the exclusion of the species from Turraea and suggested possibly close links with Munronia. In this study, parsimony, maximum likelihood and Bayesian analyses of DNA sequence data from plastid $r b c L$ and nuclear ITS rDNA were used to infer the phylogenetic position of T. breviflora and its affinities to other representatives of the family. Phylogenetic analyses support Mabberley's (1995a) proposal that the concept of the genus Munronia be expanded to accommodate it. The new combination Munronia breviflora (Ridl.) Mabb. \& Muellner is therefore made.
\end{abstract}

Key words: Meliaceae, Munronia, Sapindales, Turraea breviflora, internal transcribed spacer(ITS), $r b c L$, taxonomy.

\section{INTRODUCTION}

Turraea breviflora Ridl. (Meliaceae; Fig. 1) is a rather inconspicuous suckering shrublet now restricted to Peninsular Malaysia. It seems that it was first collected by H.N. Ridley at Serangoon, Singapore in December 1897, but the plant has not been recorded from that island since; subsequently it was collected in Selangor and Johor in what is now Peninsular Malaysia.

When Ridley described the plant as a new species in 1922, he provisionally referred it to Turraea L., a genus otherwise unknown from the peninsula, or, indeed from the wetter parts of Malesia in general (Mabberley 1995a, b). Since that time it has been collected on only a handful of other occasions and is still known from only a few localities in rather open hill Dipterocarp forest, often associated with bertam, Eugeissona tristis, and from limestone rocks. Paradoxically, it is known from some of the most well-worked sites such as Bukit Lagong and Ulu Gombak in Selangor, yet has never been found in fruit, and the number of flowering collections even from those sites is small. No doubt it is frequently overlooked, as it grows amongst tree seedlings and saplings which it greatly resembles. It is like no other Meliaceae and, in the field, sterile material may be readily confused with species of Icacinaceae or other families.

1) Grunelius-Moellgaard Laboratory, Department of Botany and Molecular Evolution, Senckenberg Research Institute, Senckenberganlage 25, D-60325 Frankfurt, Germany.

2) Herbarium, Library, Art \& Archives, Royal Botanic Gardens, Kew, Richmond, Surrey TW9 3AB, United Kingdom; Nationaal Herbarium Nederland, Universiteit Leiden branch, P.O. Box 9514, 2300 RA Leiden, The Netherlands. 


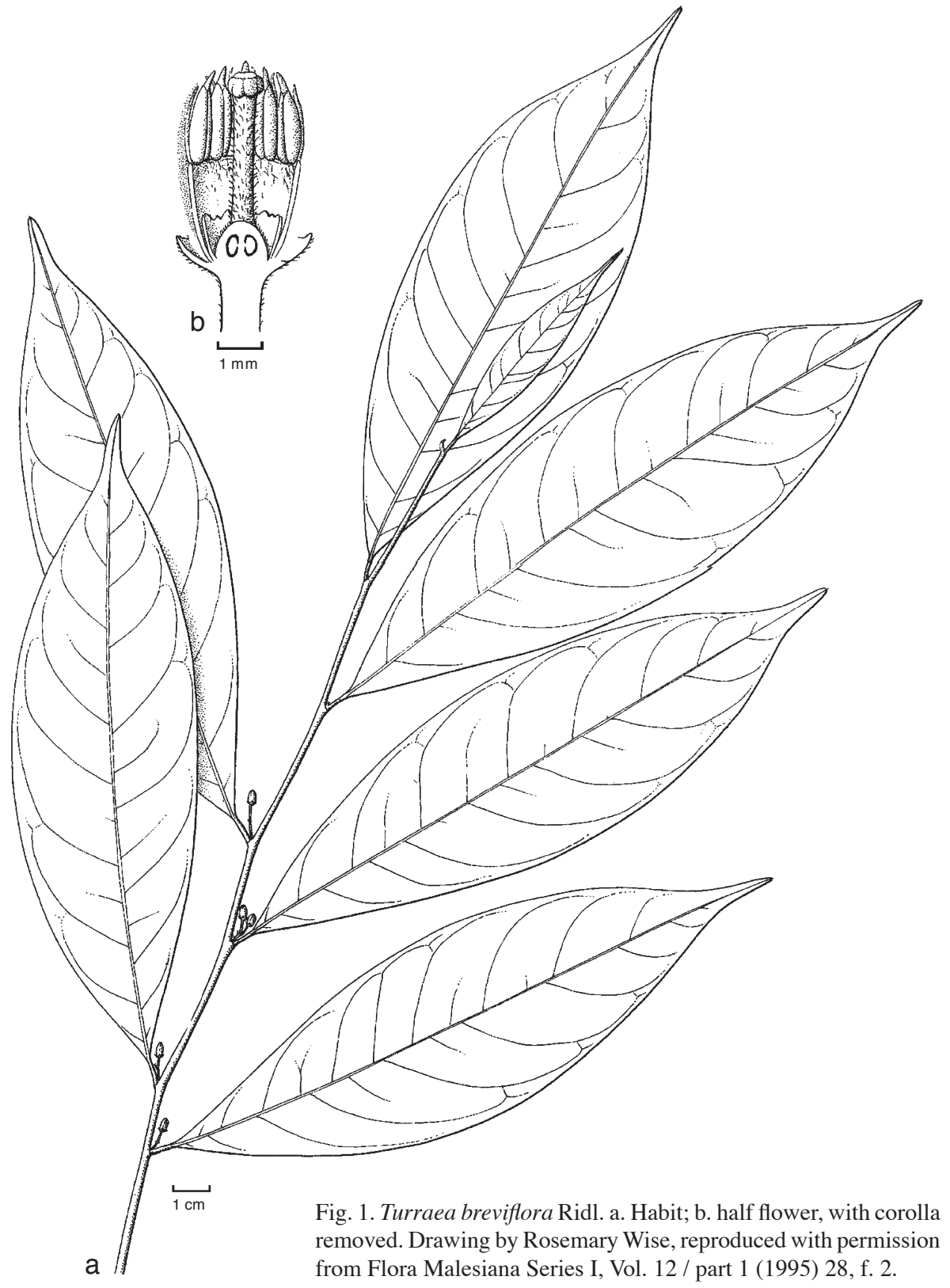

Pennington \& Styles (1975) noted that the relationships of the species were uncertain, and suggested it had "almost equal affinities with both Turraea and Munronia". In the early 1980s, when preparing an account for Flora Malesiana Mabberley (1995a: 29), who had collected the plant in the field in 1974, examined herbarium material closely and made a critical morphological analysis, leading him to exclude Turraea breviflora from genus Turraea because of its habit, indumentum, corolla aestivation, 
disk and the usual number of ovules in each locule. He pointed out that it resembled the genus Munronia Wight, as then understood, in its indumentum, but differed from that in its habit, valvate corolla, the usual number of ovules in each locule and possible dioecy. He thus concluded that it either represented an undescribed genus as Ridley had suspected, or that the concept of Munronia had to be enlarged. Today, it is the only species of the pantropical family Meliaceae which cannot confidently be placed in a genus. The writing by the second author of an account of the family Meliaceae for Flora of Peninsular Malaysia has prompted a re-examination of the plant, using molecular methods to augment the earlier morphological analysis, in an attempt to resolve its taxonomic placement.

In this study, therefore, we performed maximum parsimony (MP), maximum likelihood (ML) and Bayesian analyses of DNA sequence data from plastid $r b c L$ and the internal transcribed spacers (ITS) of nuclear ribosomal DNA (nrDNA), defined as the unit containing the ITS1 spacer, 5.8S rRNA gene, and ITS2 spacer, to infer the phylogenetic position of Turraea breviflora and its affinities to other representatives of the family. Based on 46 species of Meliaceae, including a representative sampling for the two subfamilies, all tribes and almost all genera (44 out of c. 50), we focused on the following questions:

- What is the topological position of T. breviflora in the family phylogenetic trees derived from MP, ML and Bayesian analyses?

- What are the closest relatives of T. breviflora?

- Do the results support either of Mabberley's (1995a) taxonomic proposals?

\section{MATERIALS AND METHODS}

\section{Plant material}

Plant material was collected during field excursions, taken from herbarium specimens, or obtained from the DNA bank at Kew (http:www.dnabank.kew.org). RbcL sequences of 44 taxa of Meliaceae (ingroup) and 6 other taxa (outgroup) were available from the first author's previous work on Meliaceae (Muellner et al. 2003, 2006). Our rbcL matrix includes representatives of all tribes (Pennington \& Styles 1975) of the only two currently recognised subfamilies (Muellner et al. 2003): Melioideae, viz. Turraeeae, Melieae, Vavaeeae, Trichilieae, Aglaieae, Guareeae, and Sandoriceae, and Cedreloideae (Swietenioideae), viz. Cedreleae, Swietenieae, Xylocarpeae, plus representatives of the Sapindalean families Sapindaceae, Rutaceae, and Simaroubaceae. ITS sequences of 32 taxa of Melioideae (ingroup) and four Cedreloideae (outgroup) were available from the first author's previous work on Meliaceae (Muellner et al. 2008a, b). Voucher information and GenBank accession numbers are listed in Table 1.

\section{Isolation of DNA, amplification and sequencing}

Total DNA from leaf fragments was extracted using a NucleoSpin Plant kit (Macherey-Nagel, Dueren, Germany). PCR amplification was carried out following Muellner et al. $(2003,2006,2008 \mathrm{a}, \mathrm{b})$. PCR products were cleaned using a NucleoSpin ${ }^{\circledR}$ Extract II kit (Macherey-Nagel, Dueren, Germany). Sequencing reactions were run on a CEQ ${ }^{\mathrm{TM}}$ 8800 Genetic Analysis System (Beckman Coulter, Krefeld, Germany), following the manufacturer's protocol. 
Table 1. Voucher information and GenBank accession numbers for samples used in this study (in alphabetical order). Voucher specimens are deposited in the following herbaria: ANBG = Australian National Botanic Gardens; FR = Herbarium Senckenbergianum, Senckenberg Research Institute; $\mathrm{GC}=$ University of Ghana; KEP FRI = Forestry Institute Malaysia; $\mathrm{K}=$ Royal Botanic Gardens, Kew; L = Nationaal Herbarium Nederland, Leiden University branch; LBC = Limbe Botanic Garden; $\mathrm{NCU}=$ University of North Carolina; WU = University of Vienna.

\begin{tabular}{|c|c|c|}
\hline Taxon & Voucher (Herbarium) & $\begin{array}{l}\text { GenBank accession } \\
\text { number: } r b c L \text {, ITS. }\end{array}$ \\
\hline Aglaia elaeagnoidea (A.Juss.) Benth. & Samuel 4 (WU) & AY128209 \\
\hline Aglaia odorata Lour. & Greger 903 (WU) & AY695552 \\
\hline Ailanthus altissima (Mill.) Swingle & Chase 126 (NCU) & AY 128247 \\
\hline Allophyllus cobbe (L.) Raeusch. & Chase $1306(\mathrm{~K})$ & AY 128248 \\
\hline $\begin{array}{l}\text { Anthocarapa nitidula (Benth.) } \\
\text { T.D.Penn. ex Mabb. }\end{array}$ & Chase $3313(\mathrm{~K})$ & DQ238056, DQ861616 \\
\hline Aphanamixis polystachya (Wall.) R.Parker & $\begin{array}{l}\text { Chase } 2109(\mathrm{~K}) \\
\text { Samuel } 14(\mathrm{WU})\end{array}$ & $\begin{array}{l}\text { AY128213 } \\
\text { AY695584 }\end{array}$ \\
\hline Astrotrichilia sp. & Richard $25(\mathrm{~K})$ & DQ238060, DQ861621 \\
\hline Azadirachta indica A.Juss. & Samuel 5 (WU) & AY128215, AY695594 \\
\hline Cabralea canjerana (Vell.) Mart. & Pennington $17067(\mathrm{~K})$ & DQ238055, DQ861617 \\
\hline Calodecaryia crassifolia Leroy & Croat $31521(\mathrm{~K})$ & AY128216, DQ861631 \\
\hline Capuronianthus mahafalensis Leroy & Fosberg $52439(\mathrm{~K})$ & AY 128218 \\
\hline Carapa guianensis Aubl. & Chase $2111(\mathrm{~K})$ & AY128219 \\
\hline Cedrela odorata $\mathrm{L}$. & Chase $2112(\mathrm{~K})$ & AY128220, DQ861606 \\
\hline Chisocheton macrophyllus King & Chase $1309(\mathrm{~K})$ & AY128221, DQ861613 \\
\hline Chukrasia tabularis A.Juss. & Chase $1308(\mathrm{~K})$ & AY 128223 \\
\hline Cipadessa baccifera (Roth) Miq. & Chase $1310(\mathrm{~K})$ & AY128224, DQ861627 \\
\hline Dysoxylum gaudichaudianum (A.Juss.) Miq. & Chase $1312(\mathrm{~K})$ & AY128227, DQ861619 \\
\hline Ekebergia capensis Sparrm. & MG 246 (Cynthia Morton) & AY128228, DQ861623 \\
\hline Guarea glabra Vahl & Chase $336(\mathrm{NCU})$ & AY128229, AY695591 \\
\hline Harpullia arborea (Blanco) Radlk. & Chase 2018 (ANBG) & AY128249 \\
\hline Heckeldora staudtii (Harms) Staner & Chase $3311(\mathrm{~K})$ & AY128230, AY695592 \\
\hline Humbertioturraea sp. (H. labatii Lescot ined.) & Bardot-Vaucoulon $160(\mathrm{~K})$ & DQ238058, DQ861632 \\
\hline Khay a anthotheca C.DC. & Chase $2859(\mathrm{~K})$ & AY128231, DQ861608 \\
\hline Lansium domesticum Corrêa & Chase $2113(\mathrm{~K})$ & AY128232, AY695586 \\
\hline $\begin{array}{l}\text { Lepidotrichilia volkensii (Gürke) J.-F.Leroy ex } \\
\text { Styles \& F. White }\end{array}$ & Hughes $189(\mathrm{~K})$ & DQ238061, DQ861620 \\
\hline Lovoa sywnnertonii Baker f. & Chase $2860(\mathrm{~K})$ & AY 128233 \\
\hline Malleastrum mandenense Leroy & Cheek et al. 3-17-5 (K) & DQ238062, DQ861626 \\
\hline Melia azedarach $\mathrm{L}$. & Chase $2867(\mathrm{~K})$ & AY128234, AY695595 \\
\hline Munronia humilis (Blanco) Harms & Maxwell 75-239(L) & $\begin{array}{l}\text { EU621669, } \\
\text { FJ194495/FJ194496 }\end{array}$ \\
\hline M. pinnata (Wall.) Theob. & Samuel 6 (WU) & AY128236, DQ861604 \\
\hline Naregamia alata Wight \& Arn. & Kanodia 89603 (K) & DQ238059, DQ861629 \\
\hline Nymania capensis (Thunb.) Lindb. & Chase 270 (NCU) & AY128238, DQ861633 \\
\hline Owenia vernicosa F.Muell. & Evans M3071 & DQ238063, DQ861622 \\
\hline Pseudobersama mossambicensis (Sim) Verdc. & $\begin{array}{l}\text { Bidgood, Abdallah \& } \\
\text { Vollesen } 1426(\mathrm{~K})\end{array}$ & DQ238064 \\
\hline Pseudocedrela kotschyi Harms & Asase 008 (GC) & DQ238069/70 \\
\hline Pseudoclausena chrysogyne (Miq.) T.P.Clark & Muellner 2052 (FR) & DQ238065, DQ861602 \\
\hline Quassia amara $\mathrm{L}$. & Fernando 1381 (LBC) & AY 128250 \\
\hline Quivisianthe papinae Baill. & Phillipson $1650(\mathrm{~K})$ & AY128239, DQ861605 \\
\hline $\begin{array}{l}\text { Reinwardtiodendron kinabaluense } \\
\text { (Kosterm.) Mabb. }\end{array}$ & $A L F B \quad 112 / 87(\mathrm{~K})$ & DQ238054, AY695589 \\
\hline \multirow[t]{2}{*}{ Ruagea pubescens H.Karst. } & Muellner 13 (WU) & DQ238057 \\
\hline & Pennington \& Frere 13761 (K) & AY695593 \\
\hline Ruta graveolens $\mathrm{L}$. & Chase $510(\mathrm{~K})$ & AY 128251 \\
\hline Sandoricum koetjape (Burm.f.) Merr. & Muellner 2050 (FR) & DQ861600, DQ238068 \\
\hline
\end{tabular}




\author{
Schmardaea microphylla (Hook.) H.Karst. \\ ex C.Muell. \\ Simarouba glauca DC. \\ Swietenia macrophylla King \\ Synoum glandulosum (Sm.) A.Juss. \\ S. glandulosum (Sm.) A.Juss. \\ Toona sp. \\ Trichilia emetica Vahl
}

Turraea breviflora Ridl.

Turraea heterophylla $\mathrm{Sm}$.

Turraea sericea $\mathrm{Sm}$.

Vavaea amicorum Benth.

Walsura tubulata Hiern

Xylocarpus moluccensis (Lam.) M.Roem.
Chase $746(\mathrm{~K})$

Chase 124 (NCU)

Chase 250 (NCU)

Chase $3314(\mathrm{~K})$

Schodde $5101(\mathrm{~K})$

Terrazas s.n. (K)

Chase $552(\mathrm{~K})$

Sieglstetter 15 (FR)

Kamarudin KEP FRI

51354 (KEP FRI)

Küppers 2212 (FR)

Civeyrel $1336(\mathrm{~K})$

Katik et al. 74722 (K)

Chase $1314(\mathrm{~K})$

Sandom $40(\mathrm{~K})$
AY128240

AY128252

AY128241, DQ861609

AY 128242

DQ861618

AY128243, DQ861607

AY128244

EF136577

EU621670, FJ194497

EF136578

AY128245, DQ861630

DQ238066/67,

DQ861610

AY128246, DQ861625

DQ238071

\section{Sequence editing and alignment}

Editing and assembly of the complementary strands were carried out with SeqManTM II version 5.07 (Lasergene, DNASTAR, Inc., Madison, WI, USA). Alignment of $r b c L$ sequences was performed by eye. Alignment of ITS sequences was performed following Muellner et al. (2008a, b). New sequences have been deposited in GenBank under the accession numbers EU621669-621670, FJ194495/FJ194496 and FJ194497 (http://www.ncbi.nlm.nih.gov/).

\section{Phylogenetic analysis}

MP analyses of the $r b c L$ dataset were performed using PAUP* $4.0 b 10$ (Swofford 2002). Substitutions at each nucleotide position were treated as independent, unordered, multi-state characters of equal weight (Fitch parsimony; Fitch 1971). Heuristic searches were carried out using 1000 random additions of taxa, tree bisection-reconnection (TBR) branch swapping, and the option MulTrees (keeping multiple, shortest trees), but holding only ten trees per replicate to reduce time spent in swapping on large numbers of trees. After 1000 replicates, we then used the shortest trees found as starting trees for a swapping-to-completion search (but with a tree limit of 10 000). Robustness of clades was estimated by bootstrapping (Felsenstein 1985) with 1000 replicates, using simple sequence addition, TBR branch swapping, and MulTrees, again holding ten trees per replicate. We consider $75-84 \%$ bootstrap values moderate support and $85-100 \%$ strong support. MP analyses of the ITS dataset and the combined $r b c L /$ ITS dataset were conducted as described above, except for setting no constraint on the number of trees held per replicate during heuristic searches.

ML analyses were carried out with RAxML version 2.2.1 (Stamatakis 2006; http:// icwww.epfl.ch/ stamatak/index-Dateien/Page443.htm) and PAUP* 4.0b10 (Swofford 2002), and Bayesian analyses were performed with MrBayes version 3.1.2 (Ronquist \& Huelsenbeck 2003; http://mrbayes.csit.fsu.edu/). The substitution models employed in these analyses were found using Modeltest version 3.06 (Posada \& Crandall 1998; http://darwin.uvigo.es/software/modeltest.html), which indicated the general time reversible model as best fitting our data with a proportion of invariable sites and a gamma 
shape parameter alpha to model rate heterogeneity $(\mathrm{GTR}+\mathrm{I}+\mathrm{G})$. For the Bayesian analyses, model parameters were estimated directly during two parallel runs, using four simultaneous chains and 2000000 cycles, sampling one tree every 100 generations. Trees that preceded stabilization of the likelihood value were excluded, and the remaining ones were used to calculate posterior probabilities via the construction of a majority rule consensus tree in PAUP. For the ML searches with RAxML we employed the GTR + G model, using 25 rate categories (instead of four as used in the Bayesian analyses).

\section{RESULTS}

The aligned $r b c L$ matrix consisted of 1387 characters. For the $r b c L$ matrix, 277 (20\%) positions were variable and $166(12 \%)$ were potentially parsimony informative. With the limits imposed as described above, the parsimony search produced 10000 most parsimonious trees of 552 steps with a consistency index $(\mathrm{CI})=0.53$ and a retention index $(\mathrm{RI})=0.81$. The aligned ITS matrix consisted of 785 characters; $480(61 \%)$ positions were variable and $366(47 \%)$ were potentially parsimony informative. The parsimony search produced 10 most parsimonious trees of 2072 steps with CI $=0.41$ and RI $=0.46$. The combined $r b c L /$ ITS matrix consisted of 2172 characters; $671(31 \%)$ positions were variable and $464(21 \%)$ were potentially parsimony informative. The parsimony search produced 2 most parsimonious trees of 2453 steps with $\mathrm{CI}=0.41$ and $\mathrm{RI}=0.50$.

Figures 2 and 3 show results of the ML and Bayesian analyses. Turraea breviflora is phylogenetically closest to the two representatives of the genus Munronia (Fig. 2, 3; also true for the single $r b c L$ and ITS ML and Bayesian trees, trees not shown). Accessions of T. breviflora and two species of Munronia appear in a clade (Fig. 2, 3). The monophyly of the group is very weakly supported in the Bayesian analysis of the $r b c L$ dataset (59\% posterior probability, PP, tree not shown), and receives strong support in the combined $r b c L /$ ITS analysis (100\% PP, Fig. 3). Although T. breviflora and the two species of Munronia are monophyletic in the combined MP strict consensus tree, the clade does not receive $>50 \%$ bootstrap percentage; the latter is also true for the single $r b c L$ and ITS analyses (trees not shown). In all three ML analyses, T. breviflora and Munronia appear in one clade (Fig. 2, and trees not shown).

\section{DISCUSSION}

Mabberley (1995a) argued, on morphological grounds, that, although Turraea breviflora belongs in Turraeeae, it should be excluded from Turraea and is most closely related to Munronia; this study 1) confirms the position of $T$. breviflora in a clade comprising representatives of Turraeeae and Trichilieae; 2) provides evidence that it is phylogenetically closest to Munronia; 3 ) suggests it indeed be referred to Munronia.

It should be noted here, however, that in order to reach a robust phylogenetic appreciation of Turraeeae and Trichilieae, sampling of additional taxa on species level and the collection of additional DNA data will be necessary. 


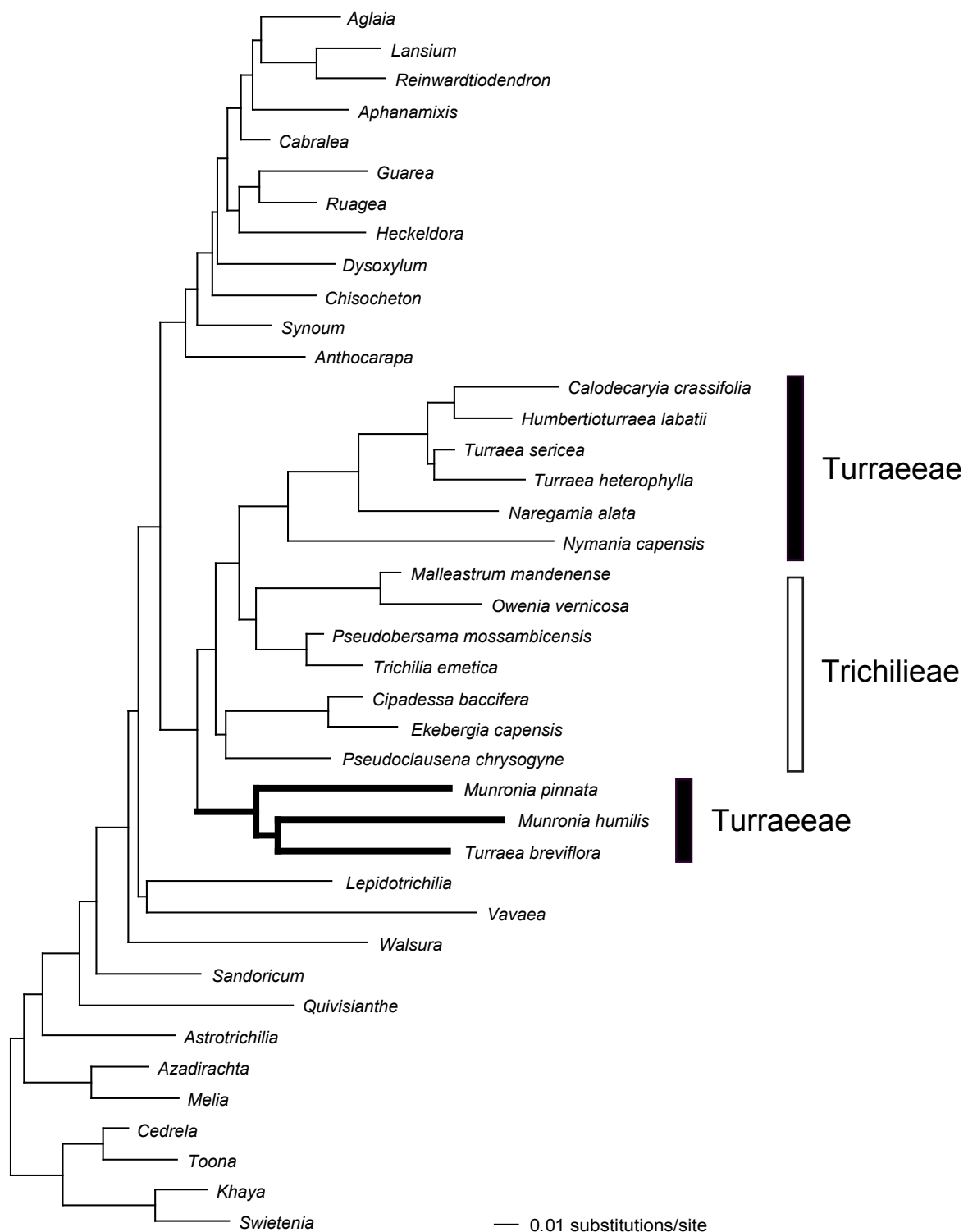

Fig. 2. ML tree obtained from the ML analysis of the combined $r b c L /$ ITS dataset of 36 Melioideae ingroup and four Cedreloideae outgroup accessions. Subfamilies after Muellner et al. (2003).

Mabberley's (1995a) proposal that the concept of the genus Munronia be expanded, is vindicated by our new findings, so that an amended description of the genus is provided below.

The last enigmatic species of Meliaceae has found a home. 


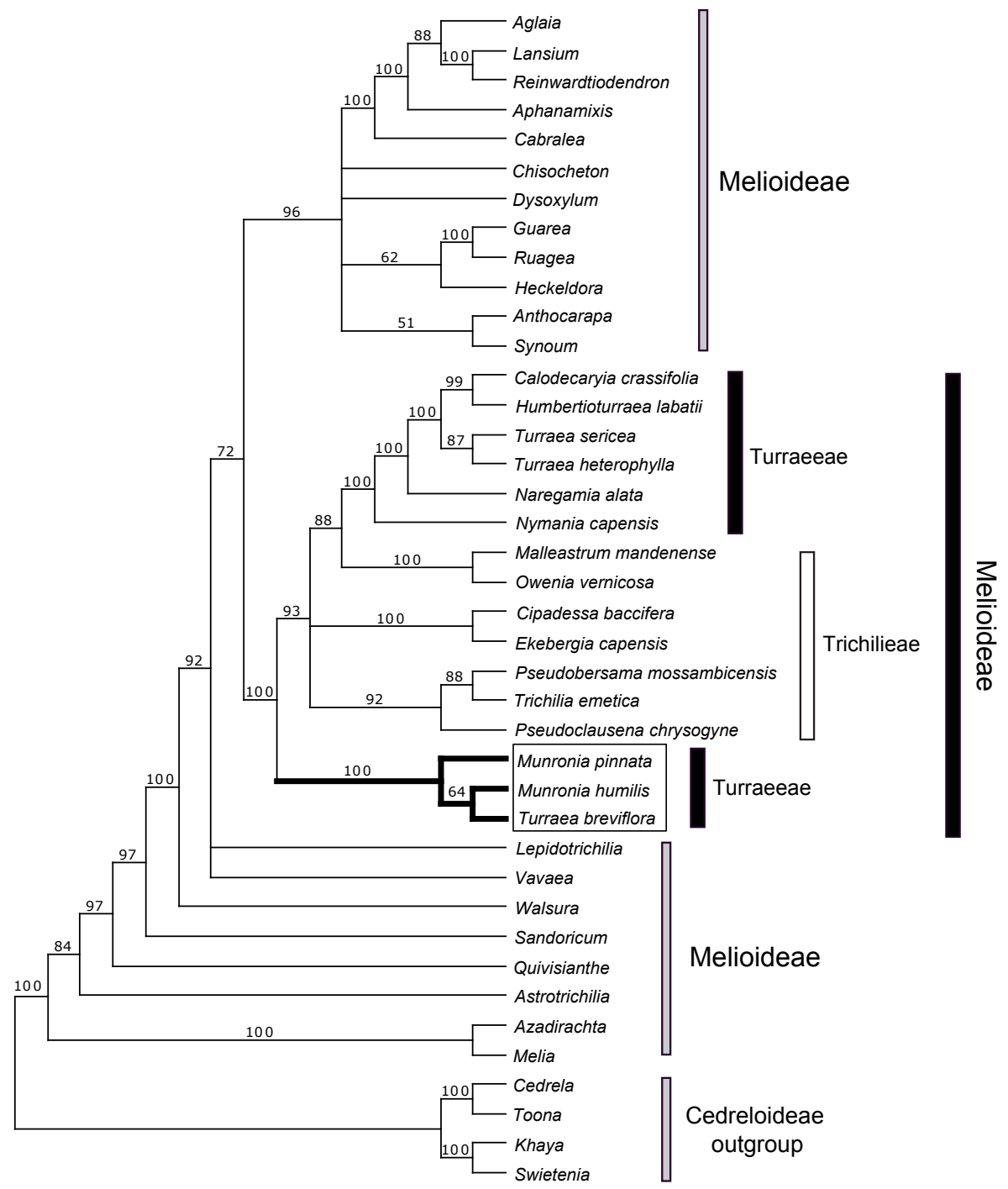

Fig. 3. Bayesian tree (10 000 total trees, burn-in of 1000 trees) of the combined $r b c L /$ ITS dataset of 36 Melioideae ingroup and four Cedreloideae outgroup accessions (50\% majority rule consensus tree). Subfamilies after Muellner et al. (2003). Numbers above branches are Bayesian posterior probabilities.

\section{MUNRONIA}

Munronia Wight (1838). - Type species: Munronia pumila Wight (= M. pinnata (Wall.) Theob.).

Unbranched or sparsely branched shrublets, sometimes suckering with apparently short-lived shoots, sometimes possibly dioecious. Indumentum a mixture of simple and bifid or stellate hairs. Leaves simple to imparipinnate, often crenate to serrate. 
Flowers hermaphrodite, solitary or in few-flowered thyrses, pseudopedicellate, usually white. Calyx 5-lobed to near base, lobes often somewhat foliaceous. Petals 5, valvate to imbricate, adnate to staminal tube basally, rarely becoming free later. Staminal tube narrowly cylindrical or weakly obconical, the margin with 10 entire or bilobed appendages or, rarely, with 10 reflexed filiform appendages recurved some distance below margin; anthers 10, pubescent, inserted on tube rim, alternating with appendages, connective often produced apically forming an appendage, which is rarely filiform. Disk 0 or tubular, free or united with base of staminal tube. Ovary (3) 5-locular, each locule with 1 or 2 superposed ovules; style-head capitate, sometimes with 5 stigmatic lobes. Fruit a 5-valved loculicidal capsule, each locule with 1 or 2 seeds. Seed planoconvex with a bony tegmen with an outgrowth enveloping a thick sarcotesta; embryo embedded in thin endosperm.

Distribution - About four species restricted to tropical Asia and subtropical China with two species in Peninsular Malaysia:

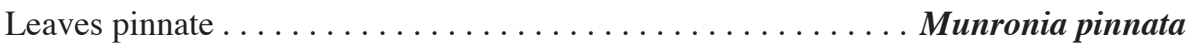

(see Mabberley 1995a, b for full descriptions and synonymy)

Leaves simple

Munronia breviflora

Munronia breviflora (Ridl.) Mabb. \& Muellner, comb. nov.

Turraea breviflora Ridl. (1922) 383; M.R.Hend. (1939) 40; Mabb. (1995a) 29, f. 2. - Type: Ridley 9114 (lectotype, selected here, K!), Singapore, Serangoon, Dec. 1897.

Suckering shrublet to $1 \mathrm{~m}$ tall, making stands of branching, whippy, blackish stems $6 \mathrm{~mm}$ diam. with distichous leaves; taproots long, tenacious. Indumentum of stellate hairs with some simple ones. Leafy twigs $2-3 \mathrm{~mm}$ diam., densely pubescent. Leaves $12-20$ by $4-5 \mathrm{~cm}$, simple, elliptic to weakly obovate, somewhat bullate in vivo, subglabrous, pale abaxially, apex gradually long-acuminate, base acute to cuneate; venation prominent on both surfaces in sicco, midrib sparsely pubescent proximally, major veins 7-10 on each side, arcuate and looped at margin. Flowers in 3-6-flowered fascicles or cymes, in axils of leaves present or lost; branches 2-4 mm long, pubescent; pedicels 4-9 mm long, pubescent. Calyx 2-3 mm tall, very shallowly cupulate, pubescent, green, the lobes triangular to $1.5 \mathrm{~mm}$ long. Petals $6-7$ by $2-3 \mathrm{~mm}$, narrowly ovate, valvate, reflexed at anthesis, white. Staminal tube a little shorter than petals, white, bearing filiform appendages alternating with anthers; each anther with an apical appendage. Disk cupuliform, short, closely encircling ovary, margin somewhat erose. Ovary 5-locular, each locule 1-ovular, or, rarely, apparently 3-locular and some locules 2-ovular, pubescent with upward-pointing simple hairs; style c. $5 \mathrm{~mm}$ long, pubescent; stylehead 5-lobed, orange. Fruit and seeds unknown.

Distribution - Collected from only a few localities in Peninsular Malaysia (Selangor, Johor) and Singapore.

Conservation status - As Munronia breviflora has not been collected in its southern sites (Johor, Singapore) for over 70 years and has never been found in fruit anywhere, while its extant populations are very restricted in Selangor, it must be considered very rare and threatened, though Bukit Lagong populations are inside a forest reserve. 
Selected specimens:

Peninsular MalaYsia. Selangor: Kepong, Bukit Lagong Forest Reserve, above reservoir, Mabberley 1566 (FHO, K, KEP) \& 16th mi, Genting Simpah Road, Selangor Ridge, Kochummen FRI 2971 (K). Johor: Sungei, Kau Ara, Corner SFN 31470 (K).

\section{ACKNOWLEDGEMENTS}

We thank Ruth Kiew and Kamarudin Saleh (FRIM, Kepong, Malaysia) for arranging the collecting of fresh material of Munronia breviflora under the Flora of Peninsular Malaysia Project; Jaap Vermeulen (Nationaal Herbarium Nederland, Leiden) for providing herbarium material of M. humilis; and Heike Henselewski (Senckenberg Research Institute, Frankfurt) for laboratory assistance. Financial support for this study was provided by the Marga and Kurt Moellgaard Fund to the first author (project no. T130/2390/2520/15159/07) and the Senckenberg Research Institute.

\section{REFERENCES}

Felsenstein, J. 1985. Confidence limits on phylogenetics: an approach using the bootstrap. Evolution 39: $783-791$.

Fitch, W.M. 1971. Toward defining the course of evolution: minimal change for a specific tree topology. Syst. Zool. 20: 406-416.

Henderson, M.R. 1939. The flora of the limestone hills of the Malay Peninsula. J. Roy. Asiat. Soc., Mal. Br. 17: 13-87.

Mabberley, D.J. 1995a. Turraea, Munronia. Flora Malesiana, Ser. I, 12: 24-34.

Mabberley, D.J. 1995b. Munronia. In: M.D. Dassanayake (ed.), A revised handbook to the Flora of Ceylon 9: 236-239. Amerind, New Delhi.

Muellner, A.N., C.M. Pannell, A. Coleman \& M.W. Chase. 2008a. The origin and evolution of Indomalesian, Australasian and Pacific island biotas: insights from Aglaieae (Meliaceae, Sapindales). J. Biogeogr. 35: 1769-1789.

Muellner, A.N., R. Samuel, M.W. Chase, A. Coleman \& T.F. Stuessy. 2008b. An evaluation of tribes and generic relationships in Melioideae (Meliaceae) based on nuclear ITS ribosomal DNA. Taxon 57: $98-108$.

Muellner, A.N., R. Samuel, S.A. Johnson, M. Cheek, T.D. Pennington \& M.W. Chase. 2003. Molecular phylogenetics of Meliaceae based on nuclear and plastid DNA sequences. Amer. J. Bot. 90: 471-480.

Muellner, A.N., V. Savolainen, R. Samuel \& M.W. Chase. 2006. The mahogany family "out-ofAfrica": divergence time estimation, global biogeographic patterns inferred from plastid rbcLDNA sequences, extant, and fossil distribution of diversity. Molec. Phylogenet. Evol. 40: 236-250.

Pennington, T.D. \& B.T. Styles. 1975. A generic monograph of the Meliaceae. Blumea 22: 419-540.

Posada, D. \& K.A. Crandall. 1998. Modeltest: testing the model of DNA substitution. Bioinformatics 14: 817-818.

Ridley, H.N. 1922. Flora of the Malay Peninsula, vol. 1. Reeve, London (July 1922: see also J. As. Soc. Str. Br. 86: 383 (Nov. 1922)).

Ronquist, F. \& J.P. Huelsenbeck. 2003. MrBayes 3: Bayesian phylogenetic inference under mixed models. Bioinformatics 19: 1572-1574.

Stamatakis, A. 2006. RAxML-VI-HPC: Maximum likelihood-based phylogenetic analyses with thousands of taxa and mixed models. Bioinformatics 22: 2688-2690.

Swofford, D.L. 2002. PAUP*. Phylogenetic analysis using parsimony (*and other methods). Version 4. Sinauer Associates, Sunderland, Massachusetts.

Wight, R. 1838. Munronia. Icones Plantarum Indiae Orientalis: or figures of Indian plants 1, 5: [1] (xi 1838). Pharoah, Madras. 